\title{
HUBUNGAN PENGETAHUAN, SITUASI, SIKAP DAN MOTIVASI DENGAN KEPUTUSAN PEMBELIAN LAPTOP
}

\author{
Bruno Hami \\ Program Studi Manajemen \\ Fakultas Ekonomi Universitas Katolik Darma Cendika \\ Jalan Dr. Ir. H. Soekarno 201, Surabaya \\ V. Ratna Inggawati \\ Program Studi Manajemen \\ Fakultas Ekonomi Universitas Katolik Darma Cendika \\ Jalan Dr. Ir. H. Soekarno 201, Surabaya
}

\begin{abstract}
The study aims to obtain empirical information that knowledge, situation, attitude and motivation have positive relationship simultaneously and partially with laptop purchasing decision from students of Economic Faculty of Catholic University Darma Cendika Surabaya. Problems and hypothesis are formulated based on references and empirical studies. To test the hypothesis used regression conversion $F$ test (linearitan) to determine whether the relationship between the dependent variable with the independent variable is linear or not. The correlation coefficient test is used to determine the size of the correlation coefficient whether significant or not. Population in this research is students of Economic Faculty of Catholic University Darma Cendika Surabaya with amount of sample counted 100 people. The end result of the study shows that the partial correlation test shows: (i) knowledge has a correlation coefficient of 0,034 with significance of $0,738>0,05$, meaning the correlation coefficient is not significant; (ii) the situation has a correlation coefficient of 0,365 with significant 0,00<0,05, meaning significant correlation coefficient; (iii) attitude of having correlation coefficient 0,416 with significance 0,00 <0,05, meaning significant correlation coefficient; and (iv) motivation has a correlation coefficient of 0,232 with a significance of 0,022<0,05, meaning the correlation coefficient is significant. Simultaneously, the dependent variable relation $(X)$ with independent variable $(Y)$ is positive with adjusted $R$ Square (R2) of 0,428 which means that 42,8\% purchase decision of laptop students of Economic Faculty of Catholic University Darma Cendika Surabaya can be explained by the four dependent variables, while the remaining $57,2 \%$ of the decision to purchase laptop students of Economic Faculty of Catholic University Darma Cendika Surabaya can be explained by other variables outside of the four dependent variables currently being studied.
\end{abstract}




\begin{abstract}
ABSTRAK
Penelitian bertujuan untuk memperoleh informasi empiris bahwa pengetahuan, situasi, sikap dan motivasi memiliki hubungan yang positif secara bersamaan (simultan) dan secara parsial dengan keputusan pembelian laptop mahasiswa Fakultas Ekonomi Universitas Katolik Darma Cendika Surabaya. Permasalahan dan hipotesis dirumuskan berdasarkan referensi dan studi empiris. Untuk menguji hipotesis digunakan regresi konversi uji F (linearitan) untuk mengetahui apakah hubungan antara variabel dependen dengan variabel independen bersifat linear atau tidak. Uji koefisien korelasi digunakan untuk mengetahui besar kecilnya koefisien korelasi apakah signifikan atau tidak. Populasi dalam penelitian ini adalah mahasiswa Fakultas Ekonomi Universitas Katolik Darma Cendika Surabaya dengan jumlah sampel sebanyak 100 orang. Hasil akhir dari penelitian memperlihatkan bahwa uji korelasi parsial menunjukkan: (i) pengetahuan memiliki koefisien korelasi sebesar 0,034 dengan signifikansi sebesar 0,738 > 0,05 , berarti koefisien korelasi tidak signifikan; (ii) situasi memiliki koefisien korelasi sebesar 0,365 dengan signifikan $0,00<0,05$, berarti koefisien korelasi signifikan; (iii) sikap memiliki koefisien korelasi 0,416 dengan signifikansi 0,00< 0,05 , berarti koefisien korelasinya signifikan; dan (iv) motivasi memiliki koefisien korelasi 0,232 dengan signifikansi 0,022 <0,05, berarti koefisien korelasinya signifikan. Secara bersama-sama (simultan) hubungan variabel dependen (X) dengan variabel independen (Y) bersifat positif dengan adjusted $R$ Square (R2) sebesar 0,428 yang artinya bahwa 42,8\% keputusan pembelian laptop mahasiswa Fakultas Ekonomi Universitas Katolik Darma Cendika Surabaya dapat dijelaskan oleh keempat variabel dependen, sedangkan sisanya sebesar 57,2\% keputusan pembelian laptop mahasiswa Fakultas Ekonomi Universitas Katolik Darma Cendika Surabaya dapat dijelaskan oleh variabel lain di luar dari keempat variabel dependen yang saat ini diteliti.
\end{abstract}

Keywords: knowledge, situation, attitude, motivation, purchasing decision.

\section{PENDAHULUAN}

Secara umum sebuah keputusan adalah seleksi terhadap dua atau lebih pilihan alternatif dalam arti pilihan alternatif harus tersedia bagi seseorang ketika ia mau mengambil keputusan. Jika seseorang mempunyai pilihan antara melakukan pembelian dan tidak melakukan, maka orang tersebut berada dalam posisi untuk mengambil keputusan.

Dalam pengambilan keputusan pembelian produk tertentu faktor pe- ngetahuan, situasi, sikap dan motivasi menjadi hal yang penting dalam proses keputusan pembelian konsumen. Pemasar perlu memeriksa tentang apa yang sudah diketahui oleh konsumen tentang suatu produk karena sangat menentukan produk apa yang dibeli, di mana mereka membeli dan kapan mereka membeli.

Melihat pentingnya pengetahuan, sikap, situasi dan motivasi terhadap keputusan pembelian suatu produk, maka penelitian untuk mengetahui 
pengaruh dari keempat faktor ini terhadap keputusan pembelian konsumen terhadap suatu produk menjadi suatu hal yang menarik.

Penelitian ini bertujuan untuk mengetahui apakah pengetahuan, situasi, sikap dan motivasi secara parsial dan bersama-sama memiliki hubungan yang kuat dan positif dengan pengambilan keputusan pembelian laptop pada mahasiswa Fakultas Ekonomi Universitas Katolik Darma Cendika Surabaya.

\section{TINJAUAN PUSTAKA Pengetahuan}

Pengetahuan adalah informasi yang disimpan dalam ingatan (Engel et al., 1994: 316). Himpunan bagian dari informasi total yang relevan dengan konsumen di dalam pasar disebut pengetahuan konsumen. Ada 3 bidang umum pengetahuan konsumen:

1. Pengetahuan Produk

Pengetahuan produk adalah kumpulan dari banyak jenis informasi yang berbeda. Kepercayaan tentang kategori produk secara umum, pengetahuan konsumen mengenai merek dapat diperoleh melalui analisa kesadaran merek dan citra merek.

2. Pengetahuan Pembelian

Pengetahuan pembelian mencakup bermacam potongan informasi yang dimiliki konsumen yang berhubungan erat dengan perolehan produk, termasuk informasi di mana produk tersebut dibeli dan kapan membeli.

3. Pengetahuan Pemakaian

Pengetahuan pemakaian mencakup informasi yang tersedia di dalam ingatan bagaimana suatu produk dapat digunakan dan apa yang di- perlukan agar benar-benar menggunakan produk tersebut. Kecukupan pengetahuan konsumen tentang pemakaian produk sangat penting, karena konsumen tentu saja lebih kecil kemungkinan membeli produk di mana mereka tidak memiliki informasi yang cukup mengenai penggunaan produk tersebut.

\section{Situasi}

Pengaruh situasional adalah kekuatan sesaat yang tidak berasal dari dalam diri seseorang atau berasal dari produk atau merek yang dipasarkan. Situasi atau kesempatan sering menentukan apa yang akan dibeli atau dikonsumsi oleh konsumen. Pengaruh situasional adalah pengaruh yang timbul dari faktor yang khusus untuk waktu dan tempat yang spesifik yang lepas dari karakteristik konsumen dan karakteristik objek (Engel et al., 1994: 233).

\section{Karakteristik Situasi Konsumen}

Adapun karakteristik situasi konsumen adalah:

a. Lingkungan Fisik: sifat nyata yang merupakan situasi konsumen lingkungan fisik, mencakup geografis, dekor, suara, aroma, penyinaran, cuaca dan konfigurasi yang terlihat.

b. Lingkungan Sosial: ada atau tidak adanya orang lain dalam situasi yang bersangkutan.

c. Waktu: Sifat sementara dari situasi (jam, hari, bulan, musim).

d. Tugas: tujuan atau sasaran tertentu yang dimiliki konsumen dalam suatu situasi. Misalnya orang yang berbelanja hadiah perkawinan seorang teman berada dalam satu situasi acuh dan tidak acuh dibandingkan 
jika ia berbelanja untuk pemakaian pribadi.

e. Keadaan Anteseden: suasana hati sementara, antara lain: kecemasan, kesenangan, kegairahan. Misalnya uang kontan yang tersedia keletihan yang dibuat oleh konsumen ke dalam situasi tersebut (Belk dalam Engel et al., 1994: 234).

\section{Sikap}

Sikap adalah kecenderungan yang dipelajari dalam berperilaku dengan cara yang menyenangkan atau tidak menyenangkan terhadap suatu objek (Schiffman dan Kanuk, 2008: 222).

\section{Pembentukan Sikap}

Pembentukan sikap, merupakan hasil pembelajaran konsumen yang sering membeli berbagai produk baru dengan merek yang dianggap menyenangkan. Dari pengondisian klasik, merek yang sudah mapan merupakan stimulan yang tidak terhindari, melalui penguatan positif telah menentukan sikap yang menyenangkan terhadap merek. Sikap dibentuk melalui proses pembelajaran yang dilakukan oleh individu sesuai dengan lingkungan di mana konsumen melakukan pembelajaran. Adapun faktor-faktor utama yang mempengaruhi pembentukan sikap antara lain:

1. Pengalaman langsung,

Pengalaman individu mengenai suatu produk dari waktu ke waktu akan membentuk sikap tertentu pada individu. Seorang gadis sangat menyukai produk-produk viva karena dia merasa puas ketika membeli bedak dan merasa cocok ketika dia membeli pembersih muka, lipstiknya, mudah diperoleh dan pelayanannya bagus.

2. Pengaruh Keluarga.

Keluarga memiliki peranan penting dalam pembentukan sikap dan perilaku seseorang. Keluarga merupakan lingkungan yang paling dekat ketika seorang konsumen melakukan interaksi yang lebih intensif dalam mengonsumsi suatu produk. Dalam beberapa penelitian menunjukkan bahwa sikap konsumen terhadap produk tertentu memiliki hubungan yang kuat dengan sikap orang tuanya terhadap produk tersebut. Seorang remaja putri menggunakan berbagai produk kecantikan seperti yang digunakan orang tuanya, karena merasa cocok.

3. Teman Sebaya.

Teman sebaya mempunyai peran penting dalam pembentukan sikap seseorang terutama anak-anak remaja. Mereka terdorong oleh keinginan untuk diterima oleh teman sebayanya, sehingga anak-anak remaja mudah lebih banyak dipengaruhi oleh kelompoknya dari pada sumber-sumber lainnya. Misalnya kesukaan terhadap merek sepatu, tas, pakaian, telepon genggam, konsumen remaja cenderung dipengaruhi oleh rekan sebayanya.

4. Pemasaran langsung.

Pemasaran secara langsung atas produk yang ditawarkan melalui komunikasi (telepon, surat) yang disampaikan kepada konsumen akan berpengaruh dalam pembentukan sikap konsumen.

5. Tayangan Media Massa.

Media massa merupakan sarana komunikasi yang setiap saat di- 
jumpai oleh konsumen dapat membentuk sikap konsumen. Karena perannya begitu besar dalam pembentukan sikap konsumen, maka pemasar perlu mengetahui media massa apa yang biasanya dikonsumsi oleh pasar sasarannya.

\section{Motivasi dan Motif}

Menurut Jeffrey dalam Suryani (2008: 27) proses motivasi terjadi karena adanya kebutuhan, keinginan maupun harapan yang tidak terpenuhi yang menyebabkan timbulnya ketegangan. Menurut pakar perilaku konsumen, rasional dalam pengertian ekonomi tradisional menganggap bahwa para konsumen berperilaku rasional, jika secara teliti mereka mempertimbangkan semua alternatif dan memilih alternatif yang memberikan kegunaan terbesar.

Dalam konteks pemasaran, rasionalitas menyatakan bahwa konsumen memiliki sarana berdasarkan kriteria yang benar-benar objektif. Misalnya, ukuran, berat, harga, sedangkan motif emosional dalam arti pemilihan sarana menurut kriteria pribadi atau subjektif contohnya kebanggaan, ketakutan, kasih sayang atau status.

Ada tiga metode yang dapat digunakan untuk mengukur motif konsumen (Suryani, 2008: 44) yaitu:

a. Metode Wawancara Mendalam

Metode ini dipakai oleh pemasar ketika mereka ingin mengetahui secara lebih mendalam tentang manfaat yang diinginkan konsumen dan apa yang penting menurut konsumen, sehingga terdorong untuk memilih atau membeli produk tertentu.

b. Metode Tes Proyektif
Dalam metode ini konsumen ditanya tentang reaksi dan pendapat orang lain seandainya dalam situasi tertentu, apa yang mendorongnya, apa yang memotivasinya dan bagaimana pendapatnya.

c. Metode Kuisioner

Metode ini selain dapat digunakan sendiri (tanpa dilengkapi dengan pengumpulan data yang lain), seringkali digunakan sebagai pelengkap metode wawancara. Kuesioner digunakan untuk memandu dalam memberikan pertanyaan-pertanyaan pada saat melakukan wawancara.

Mengenai motivasi ada beberapa teori yang dapat digunakan, antara lain:

a. Teori Hirarki Kebutuhan menurut Winardi (Suryani, 2008: 39) merupakan proposisi yang disampaikan Maslow mengenai motivasi dalam kaitannya dengan perilaku manusia yaitu:

$\square$ Manusia sebagai makhluk yang serba berkeinginan akan senantiasa menginginkan sesuatu yang lebih banyak. Jika suatu kebutuhan sudah dipenuhi akan timbul kebutuhan baru dan proses ini akan berlangsung terus selama manusia masih hidup.

$\square$ Sebuah kebutuhan yang terpenuhi bukanlah sebuah motivator perilaku, hanya kebutuhan yang tidak terpenuhi yang akan memotivasi individu untuk melakukan sesuatu tertentu.

- Kebutuhan manusia tersusun secara berjenjang. Manusia memiliki lima macam kebutuhan yang tersusun secara berjenjang 
(hirarki) mulai dari kebutuhan yang paling dasar yaitu kebutuhan fisiologis hingga kebutuhan aktualisasi diri.

b. Teori Kebutuhan dari Clelland.

Menurut Clelland (Suryani, 2008:

43) manusia memiliki tiga macam kebutuhan yaitu:

$\square$ Kebutuhan Berkuasa (need for power).

Kebutuhan ini dapat dilihat seberapa jauh individu berkeinginan untuk mengendalikan dan mempengaruhi orang lain serta objek-objek lain yang ada di lingkungannya. Kebutuhan untuk berkuasa ini sifatnya interpersonal dan berkenaan dengan interaksi individu dengan orang lain. Kekuasaan sering disimbolkan dengan simbol-simbol tertentu dalam interaksi sosial. Misalnya membeli mobil BMW, karena BMW mobil berkelas dan dikesankan masyarakat sebagai mobil eksekutif muda.

$\square$ Kebutuhan Berafiliasi.

Kebutuhan ini merupakan kebutuhan individu untuk mendapatkan kehangatan dan menjalin hubungan yang lebih dekat dengan orang lain. Individu yang memilih motif berafiliasi tinggi akan cenderung lebih ekspresif dalam mengungkapkan ambisi dan menjalin hubungan lebih dengan banyak orang.

$\square$ Kebutuhan Berprestasi.

Individu yang memiliki kebutuhan berprestasi memiliki ciriciri antara lain memiliki dorongan yang kuat untuk memperkerjakan pekerja dengan hasil terbaik dan menyukai persaingan pekerja yang menantang dan mampu menentukan tujuan sesuai dengan kemampuan.

\section{Pengambilan Keputusan}

Keputusan adalah seleksi terhadap dua pilihan alternatif atau lebih. Menurut Setiadi (2003: 415) pengambilan keputusan konsumen adalah proses pengintegrasian yang mengombinasikan pengetahuan untuk mengevaluasi dua atau lebih perilaku alternatif dan memilih salah satu diantaranya berdasarkan kriteria pemilihan yang ditetapkan.

Ada 5 tahap dalam proses pengambilan keputusan pembelian konsumen, yaitu:

1. Pengenalan Masalah.

Dalam hal ini proses pembelian akan dimulai ketika pembeli mengenali masalah atau kebutuhan tersebut yang dapat muncul oleh karena ada rangsangan internal yaitu rasa lapar, haus, seks mencapai ambang batas tertentu dan mulai menjadi pendorong dan rangsangan eksternal yaitu iklan yang memicu pikiran untuk melakukan pembelian.

2. Pencarian Informasi.

Setelah ada kebutuhan, maka konsumen terdorong untuk mencari informasi sebanyak-banyaknya yaitu mencari bahan bacaan, menelpon teman, pergi mengunjungi toko untuk mempelajari produk tertentu. Schiffman dan Kanuk (2008: 235) menyatakan ada beberapa sumber informasi dari konsumen dalam mengambil keputusan pembelian yaitu:

- Sumber pribadi: keluarga, teman, tetangga, kenalan. 
- Sumber komersial: iklan, wiraniaga, penyalur, kemasan, pajangan di toko.

- Sumber publik: media massa, organisasi penentu peringkat konsumen.

- Sumber Pengalaman: penanganan, pengkajian, dan pemakaian produk.

3. Evaluasi Alternatif.

Konsumen mengolah informasi merek yang bersaing dan membuat penilaian akhir. Dalam melaksanakan pembelian konsumen dapat mengambil lima sub keputusan yaitu merek, dealer, kuantitas, waktu (akhir pekan) dan metode pembayar (kartu kredit).

\section{Hipotesis Penelitian}

Hipotesis penelitian yang diajukan adalah:

1. Hipotesis pertama $(\mathrm{H} 1)$ :

Ada hubungan yang positif antara pengetahuan dengan keputusan pembelian laptop mahasiswa Fakultas Ekonomi Universitas Katolik Darma Cendika Surabaya.

2. Hipotesis kedua (H2):

Ada hubungan yang positif antara situasi dengan keputusan pembelian laptop mahasiswa Fakultas Ekonomi Universitas Katolik Darma Cendika Surabaya.

3. Hipotesis ketiga $(\mathrm{H} 3)$ :

Ada hubungan yang positif antara sikap dengan keputusan pembelian laptop mahasiswa Fakultas Ekonomi Universitas Katolik Darma Cendika Surabaya.

4. Hipotesis keempat (H4):

Ada hubungan yang positif antara motivasi dengan keputusan pembelian laptop mahasiswa Fakultas
Ekonomi Universitas Katolik Darma Cendika Surabaya.

\section{METODE PENELITIAN \\ Objek Penelitian}

Objek dalam penelitian ini yaitu pengetahuan, situasi, sikap dan motivasi yang merupakan dasar dalam pengambilan keputusan pembelian konsumen, baik berupa barang maupun jasa.

\section{Identifikasi Variabel}

Variabel yang digunakan dalam penelitian ini antara lain:

1. Variabel bebas (independen) yaitu:
a) Pengetahuan (X1).
b) Situasi (X2).
c) Sikap (X3).
d) Motivasi (X4).

2. Variabel terikat (dependen) yaitu keputusan pembelian (Y).

\section{Definisi Operasional Variabel}

Variabel-variabel yang akan diteliti dalam penelitian ini yaitu :

1. Pengetahuan (X1).

Pengetahuan konsumen adalah himpunan bagian dari informasi total yang relevan dengan fungsi konsumen dalam pasar. Pengetahuan konsumen tentang produk adalah semua informasi yang diperoleh konsumen yang relevan dengan produk.

2. Situasi (X2).

Situasi adalah pengaruh yang timbul dari faktor yang khusus untuk waktu dan tempat yang spesifik dan lepas dari karakteristik konsumen dan karakteristik objek.

3. Sikap (X3).

Sikap adalah suatu evaluasi menyeluruh yang memungkinkan orang merespon dengan cara menguntung- 
kan atau tidak menguntungkan pada objek atau alternatif yang diberikan. Sikap juga diartikan sebagai kecenderungan yang dipelajari dalam berperilaku dengan cara yang menyenangkan terhadap suatu objek tertentu.

4. Motivasi (X4).

Motivasi adalah kebutuhan, keinginan maupun harapan yang tidak terpenuhi yang menyebabkan timbulnya ketegangan. Jadi, motivasi muncul karena adanya kebutuhan yang dirasakan oleh konsumen .

5. Keputusan Pembelian (Y).

Keputusan pembelian adalah keputusan sebagai suatu pemilihan tindakan dari dua atau lebih pilihan alternatif.

\section{Sumber Data}

Sumber data dalam penelitian ini yaitu data primer dan data sekunder dan terdiri dari:

a. Data primer yaitu data yang diperoleh secara langsung dari sumber yaitu responden dan melalui penyebaran kuisioner.

b. Data sekunder yaitu data yang diperoleh melalui dokumen-dokumen atau catatan dari organisasi tentang jumlah mahasiswa dan struktur organisasi.

\section{Populasi Dan Sampel}

1. Populasi.

Yang menjadi populasi dalam penelitian ini adalah mahasiswa Fakultas Ekonomi Universitas Katolik Darma Cendika Surabaya

2. Sampel.

Menurut Roscoe dalam Soegiyono (2014: 164) ukuran sampel yang layak dalam penelitian ada- lah 30 sampai 500. Berdasarkan pendapat tersebut, maka dipilih jumlah sampel sebesar 100 orang.

\section{Teknik Pengumpulan Data}

Data yang digunakan dalam penelitian ini diperoleh dengan menggunakan kuisioner dan akan diukur dengan skala Likert.

\section{Analisis Data}

Data yang terkumpul dalam penelitian akan dianalisis dengan menggunakan model korelasi. Dalam model ini variabel independen dihubungkan dengan variabel dependen tanpa ada perbedaan perlakuan. Pada penelitian korelasional ada 2 macam variabel, yaitu variabel prediksi dan variabel kriteria (Noor, 2014: 46-47). Persamaan korelasi yang akan digunakan adalah sebagai berikut:

$\mathrm{Y}=\operatorname{pyx} 1 \mathrm{X} 1+\operatorname{pyx} 2 \mathrm{X} 2+$ pyx $3 \mathrm{X} 3$

\section{ANALISIS DAN PEMBAHASAN Deskripsi hasil Penelitian}

Tanggapan responden tentang hubungan pengetahuan, situasi, sikap dan motivasi dengan pengambilan keputusan pembelian laptop pada mahasiswa Fakultas Ekonomi Universitas Katolik Darma Cendika Surabaya untuk masing-masing variabel seperti diuraikan di bawah ini.

\section{Hubungan Keputusan Membeli (Y) dengan Pengetahuan (X1)}

Analisis data menunjukan bahwa ada 95\% mahasiswa membeli laptop yang mereknya sudah sangat dikenal, 93\% membeli laptop yang kualitas sudah sangat dikenal dan $80 \%$ membeli pada tempat penjualan yang sudah sangat dikenal. 
Hubungan Keputusan Membeli (Y) dengan Situasi (X2)

Analisis data menunjukan bahwa ada $87 \%$ mahasiswa membeli laptop karena banyak tugas kuliah yang harus dikerjakan, 50\% mahasiswa membeli laptop karena biaya rental mahal, $48 \%$ mahasiswa membeli laptop karena ada promo atau karena ada perubahan harga dan $60 \%$ mahasiswa tidak setuju membeli laptop karena omongan teman-teman dan sales.

\section{Hubungan Keputusan Membeli (Y) dengan Sikap (X3)}

Dari analisis data menunjukan bahwa ada 96\% mahasiswa senang membeli laptop karena sangat mendukung dalam kelancaran pengerjaan tugas-tugas kuliah, 93\% mahasiswa senang membeli laptop karena mudah dibawa kemana-mana dan 93\% mahasiswa senang membeli laptop karena lebih mudah untuk mengakses informasi-informasi.

\section{Hubungan Keputusan Membeli (Y) dengan Motivasi (X4)}

Analisis data menunjukan bahwa ada 96\% mahasiswa yang membeli laptop karena mereka butuh, 85\% mahasiswa membeli laptop karena yang harganya sesuai dengan budget dan 51\% mahasiswa membeli laptop karena mahalnya biaya rental serta $29 \%$ mahasiswa tidak setuju kalau mereka membeli laptop karena biaya rental mahal.

\section{Deskripsi Keputusan Membeli (Y)}

Dari hasil analisis data ada $89 \%$ mahasiswa membeli laptop yang merk, kualitas, harga, dan tempat jual sudah diketahui. Ada 74\% mahasiswa mem- beli laptop karena situasi tertentu, dan 53\% mahasiswa membeli laptop karena sangat mendukung kelancaran dalam mengerjakan tugas-tugas, mengakses informasi, dan mudah dibawa kemana-mana.

\section{Uji Validitas.}

Uji validitas dilakukan dengan menggunakan program SPSS 17.0. Dari hasil uji validitas diperoleh hasil $r$ hitung $>r$ tabel $(0,197)$, yang berarti pernyataan-pernyataan dalam kuisioner adalah valid.

\section{Uji Reliabilitas}

Hasil uji reliabilitas menghasilkan angka cronbach's alpha $=0,751 \geq$ 0,60 yang berarti reliabel.

\section{Uji Normalitas dan Linearitas Pengujian Normalitas}

Hasil uji normalitas menunjukkan bahwa grafik histogram memberi pola distribusi yang tidak miring ke kiri atau ke kanan, yang berarti data terdistribusi normal. Sedangkan pada grafik normal plot terlihat bahwa titiktitik menyebar berhimpitan dengan garis diagonal yang menunjukkan bahwa residual terdistribusi secara normal. Gambaran dua grafik ini menunjukkan bahwa model regresi memenuhi asumsi normal.

\section{Pengujian Linearitas}

Hasil pengujian dengan SPSS 17.0 menunjukkan bahwa $\mathrm{F}$ hitung sesuai/cocok (deviation from linierity).

\section{Pengujian Hipotesis}

Hasil pengujian hipotesis/koefisien korelasi (r) menunjukkan hasilhasil seperti diuraikan di bawah ini. 
Korelasi antara Pengetahuan (X1) dengan Keputusan Membeli (Y)

Hasil uji dengan SPSS 17.0 menunjukkan bahwa pengetahuan memiliki koefisien korelasi sebesar 0,034 dengan signifikansi sebesar 0,738 > 0,05 , berarti Ho diterima dan $\mathrm{H} 1$ ditolak. Hal itu artinya koefisien korelasi pengetahuan sangat rendah, dan tidak signifikan. Temuan ini dapat diinterpretasikan bahwa pengetahuan konsumen (X1) tidak cukup untuk menjelaskan model korelasi atau konsumen beranggapan bahwa pengetahuan tidak begitu penting dalam pengambilan keputusan mahasiswa untuk membeli laptop (Y).

Hal ini juga menunjukkan bahwa walaupun mungkin pengetahuan konsumen tentang suatu produk (laptop) lengkap, tetapi tidak menentukan dalam keputusan untuk membeli laptop. Dengan demikian hipotesis pertama (H1) ditolak artinya tidak ada hubungan yang positif antara pengetahuan dengan keputusan pembelian laptop dari mahasiswa Fakultas Ekonomi Universitas Katolik Darma Cendika Surabaya.

\section{Korelasi antara Situasi (X2) dengan} Keputusan Membeli (Y)

Hasil uji dengan SPSS 17.0 menunjukkan bahwa situasi memiliki koefisien korelasi sebesar 0,365 dengan signifikansi sebesar $0,000<0,05$, berarti Ho ditolak dan $\mathrm{H} 1$ diterima. Hal itu artinya koefisien korelasi pada variabel situasi rendah dan signifikan, artinya bahwa semakin kompleks situasi yang dialami dan dirasakan oleh mahasiswa, maka akan mendesak mahasiswa untuk mengambil keputusan membeli laptop (Y).
Hal ini juga menunjukkan bahwa situasi yang dihadapi konsumen sangat menentukan dalam keputusan mahasiswa dalam membeli laptop. Dengan demikian hipotesis kedua (H2) diterima artinya ada hubungan yang positif antara situasi dengan keputusan pembelian laptop mahasiswa Fakultas Ekonomi Universitas Katolik Darma Cendika Surabaya.

\section{Korelasi antara Sikap (X3) dengan Keputusan Membeli (Y)}

Hasil uji dengan SPSS 17.0 menunjukkan bahwa sikap (X3) memiliki koefisien korelasi sebesar 0,416 dengan signifikansi sebesar $0,00<0,05$, berarti Ho ditolak dan $\mathrm{H} 1$ diterima. Hal itu artinya koefisien korelasi sikap sedang dan signifikan. Temuan ini dapat diinterpretasikan bahwa sikap (X3) berhubungan positif terhadap keputusan pembelian laptop mahasiswa, yang berarti semakin dirasakan bahwa laptop cukup mendukung kelancaran proses penyelesaian tugastugas kuliah. Oleh karena itu sikap menentukan untuk pengambilan keputusan membeli laptop (Y).

Hal ini juga menunjukkan bahwa sikap (X3) menentukan dalam keputusan membeli. Dengan demikian hipotesis ketiga (H3) diterima artinya ada hubungan yang positif antara sikap dengan keputusan pembelian laptop mahasiswa Fakultas Ekonomi Universitas Katolik Darma Cendika Surabaya.

\section{Korelasi antara Motivasi (X4) dengan Keputusan Membeli (Y)}

Hasil uji dengan SPSS 17.0 menunjukkan bahwa motivasi (X4) memiliki koefisien korelasi sebesar 
0,232 dengan signifikansi sebesar $0,022<0,05$, berarti Ho ditolak dan H1 diterima. Temuan ini dapat diinterpretasikan bahwa motivasi (X4) konsumen cukup untuk menjelaskan model korelasi atau dengan kata lain bahwa motivasi dari konsumen mempunyai hubungan yang penting dalam pengambilan keputusan pembelian laptop mahasiswa (Y), yang artinya bahwa motivasi akan menentukan dalam pengambilan keputusan mahasiswa membeli laptop.

Hal ini juga menunjukkan bahwa motivasi (X4) menentukan dalam keputusan membeli. Dengan demikian hipotesis keempat (H4) diterima artinya ada hubungan yang positif antara motivasi dengan keputusan pembelian laptop mahasiswa Fakultas Ekonomi Universitas Katolik Darma Cendika Surabaya.

\section{Hubungan Pengetahuan (X1), Situasi (X2), Sikap (X3) dan Motivasi (X4) dengan Keputusan Membeli (Y)}

Hasil pengolahan data dengan SPSS 17.0 mengenai hubungan antara pengetahuan (X1), situasi (X2), sikap (X3) dan motivasi (X4) dengan keputusan membeli (Y) menghasilkan persamaan linear sebagai berikut:

$\mathrm{Y}=0,034 \mathrm{X} 1+0,365 \mathrm{X} 2+0,416 \mathrm{X} 3$ $+0,232 \mathrm{X} 4$

Untuk menginterpretasikan koefisien korelasi dapat digunakan pedoman dari Sugiyono (2014) yang menyatakan sebagai berikut:

$\begin{array}{ll}0,00-0,199 & : \text { Sangat Rendah } \\ 0,20-0,399 & : \text { Rendah } \\ 0.40-0,599 & : \text { Sedang } \\ 0,60-0,799 & : \text { Kuat } \\ 0,80-1,000 & \text { : Sangat Kuat }\end{array}$

Dari tampilan output SPSS 17.0 model summary menunjukkan besarnya adjusted R2 adalah 0,428, yang artinya bahwa $42,8 \%$ keputusan pembelian laptop dari mahasiswa Fakultas Ekonomi Universitas Katolik Darma Cendika dapat dijelaskan oleh empat variabel independen yaitu pengetahuan, sikap, situasi dan motivasi. Sedangkan sisanya yaitu $57,2 \%$ dijelaskan oleh sebab-sebab yang lain di luar model. Standard Error of Estimate (SEE) sebesar 0,42467. Semakin kecil nilai dari SEE, maka model regresi semakin tepat dalam memprediksi variabel dependen yaitu keputusan pembelian.

\section{SIMPULAN}

1. Walaupun banyak yang diketahui konsumen tentang suatu produk (laptop), tapi tetap tidak ada hubungannya dengan pengambilan keputusan mahasiswa untuk membeli laptop. Dapat dikatakan pula bahwa pengetahuan tidak menentukan dalam pengambilan keputusan membeli konsumen.

2. Situasi mahasiswa yaitu dengan semakin banyaknya tugas-tugas kuliah mempunyai hubungan yang kuat terhadap keputusan mahasiswa untuk membeli laptop.

3. Sikap konsumen berhubungan positif dengan pengambilan keputusan pembelian laptop mahasiswa. Hal ini dapat diartikan bahwa semakin dirasa penting laptop dalam mendukung pengerjaan tugas-tugas kuliah, maka semakin kuat hubungan sikap dalam menentukan keputusan mahasiswa membeli laptop.

4. Motivasi konsumen sedikit berhubungan dengan pengambilan kepu- 
tusan pembelian laptop mahasiswa. Hal ini dapat diartikan bahwa motivasi ada hubungan dengan keputusan pembelian suatu laptop oleh mahasiswa.

5. Dari ke empat variabel independen yang dimasukkan dalam model korelasi, variabel situasi, sikap dan motivasi yang signifikan, sedangkan variabel pengetahuan tidak signifikan.

6. Keputusan pembelian laptop mahasiswa Fakultas Ekonomi Universitas Katolik Darma Cendika sebesar $42,8 \%$ mempunyai hubungan dengan variabel pengetahuan, situasi, sikap dan motivasi. Sedangkan sisanya sebesar $57,2 \%$ berhubungan dengan variabel-variabel lain di luar keempat variabel yang telah diteliti.

\section{SARAN}

Keputusan mahasiswa Fakultas Ekonomi Universitas Katolik Darma Cendika sebesar 42,8\% mempunyai hubungan dengan variabel pengetahuan, situasi, sikap dan motivasi. Sedangkan sisanya sebesar $57,2 \%$ mempunyai hubungan dengan variabel-variabel yang lain. Untuk itu disarankan bagi para peneliti untuk meneliti pada masalah yang sama guna mencari variabel-variabel lain yang mempunyai hubungan sebesar 57,2\% dengan keputusan untuk membeli di luar empat variabel tersebut di atas.

\section{DAFTAR KEPUSTAKAAN}

Engel, James F., Roger D. Blackwell and Paul W. Miniard, 1994, Perilaku Konsumen, Edisi ke 6, Jilid 1, Alih Bahasa F.X. Budiyanto, Binarupa Aksara, Jakarta.
Ferdiand, Agusty, 2012, Struktur Equation Modeling Dalam Penelitian Manajemen, Penerbit BP Universitas Diponegoro, Semarang.

Ghozali, Imam 2000, Aplikasi Analisis Multi Variate dengan Program SPSS, Cetakan Keempat, Badan Penerbit Universitas Diponegoro, Semarang.

Indriantoro, Nur dan Bambang Supomo, Metodologi Penelitian Bisnis untuk Akuntansi dan Manajemen, 1999, Edisi Pertama, BPFE UGM, Yogyakarta.

Kotler and Amstrong, 2001, DasarDasar Manajemen Pemasaran, Jilid I, Alih Bahasa oleh Alexander Sindoro, PT. Indeks Kelompok Gramedia, Jakarta.

Noor, Juliansyah, 2014, Analisis Data Penelitian Ekonomi dan Manajemen, Cetakan Pertama, PT. Grasindo, Jakarta.

Schiffman, L.G. dan L.L. Kanuk, 2008, Perilaku Konsumen, Edisi Indonesia, Cetakan Pertama, Liberty, Yogyakarta.

Setiadi, Nugroho J., 2003, Perilaku Konsumen, Edisi Revisi, Prenadademia Group, Jakarta.

Sugiyono, 2014, Metode Penelitian Manajemen, Cetakan Ketiga, Penerbit Alfabeta Bandung.

Suryani, Tatik, 2008, Perilaku Konsumen: Implikasi Pada Strategi Pemasaran, Edisi Pertama, Graha Ilmu, Yogyakarta. 